\title{
Programa "Visite Nossa Cozinha": Integração Entre Clientes de Creche e Colaboradores de uma Unidade de Nutrição Hospitalar
}

\author{
Jorge, Andréa Luiza; Carvalho, Juliana Toledo P. de; Ferreira, Michele Cristina; \\ Fernandes, Renata; Silva, Alessandra Moniz da; Evazian, Denise \\ Instituto Central - HCFMUSP - andrea.jorge@hc.fm.usp.br
}

Introdução: a Unidade de Nutrição de um hospital público de grande porte tem diversidade de clientes atendidos, inclusive crianças da creche, filhos de colaboradores que atuam na instituição. uma creche é um estabelecimento educativo que ministra apoio pedagógico e cuidados às crianças com idade entre 3 meses e 3 anos e 11 meses, que oferece vivências, interações e tem a função de auxiliar no papel educativo com ênfase no desenvolvimento integral da criança, inclusive com fornecimento de alimentação equilibrada. a alimentação oferecida às crianças é variada e compreende desde fórmulas infantis a lactentes até alimentação infantil adaptada a cada faixa etária, ambas sob responsabilidade de preparo pela Unidade de Nutrição e Dietética deste hospital. a parceria entre a unidade de nutrição e os clientes é fundamental para o convívio humanizado, melhoria dos processos e produtos, identificação de expectativas e qualidade no atendimento. Objetivos: Implementar a integração profissional, promover atualização de informações e estreitar o convívio social de funcionários de uma unidade produtora de refeições hospitalares e clientes de creche hospitalar. Métodos: o projeto iniciou-se em 2012 em uma Unidade de Nutrição e Dietética hospitalar pública em parceria com a creche hospitalar com capacidade de atendimento para 350 crianças. Inicialmente houve o planejamento de reuniões para a integração da equipe de nutricionistas da Unidade de Nutrição e Dietética com diretoria e nutricionista da creche hospitalar. Após as reuniões foi criado o programa "Visite nossa cozinha" abrangendo visita de crianças matriculadas em maternal (idade de 3 anos a 3 anos e 11 meses) e de funcionários da creche à cozinha e visita de funcionários da cozinha à creche. a unidade de nutrição organizou o roteiro de visita, o trajeto percorrido, a demonstração de fórmulas infantis e alimentos comumente distribuídos pelo Lactário e Cozinha, fotografias dos participantes e a interação com a equipe de trabalho responsável pelos processos produtivos. a creche organizou a distribuição dos grupos de visita em condições de segurança, distribuiu lembranças elaboradas pelas crianças e educadoras e sorteou duas cestas de alimentos para os colaboradores da nutrição arrecadadas pelas mães das crianças. Resultados: nos anos de 2012 e 2013 foram realizadas 10 visitas de intercâmbio ( 6 visitas da equipe creche à cozinha; 4 visitas da equipe da cozinha à creche) envolvendo cerca de 60 crianças e 44 colaboradores (creche - estagiários de nutrição, coordenador pedagógico, equipe de enfermagem e psicóloga; cozinha - nutricionistas atendentes de nutrição e cozinheiros) e total de 18 horas de atividades. Conclusões: o programa permitiu a integração entre a creche e a unidade de nutrição e estreitou o convívio humanizado na busca de melhorias contínuas.

Jorge, Andréa Luiza; Carvalho, Juliana Toledo P. de; Ferreira, Michele Cristina; Fernandes, Renata; Silva, Alessandra Moniz da; Evazian, Denise. Programa "Visite Nossa Cozinha": Integração Entre Clientes de Creche e Colaboradores de uma Unidade de Nutrição Hospitalar. In: Anais do Congresso Internacional de Humanidades \& Humanização em Saúde [= Blucher Medical Proceedings, num.2, vol.1]. São Paulo: Editora Blucher, 2014. ISSN 2357-7282

DOI 10.5151/medpro-cihhs-10464 